\title{
Korean and Chinese Consumers' Perception on Herbal Cosmetics: Clustering of Unstructured data
}

Xuan-Kun Fan, Joon-Ho Seon, Kyu-Hye Lee*

Human-Tech Convergence Program, Department of Clothing and Textiles, Hanyang University, Seoul, Korea

\author{
*Corresponding author: Kyu-Hye Lee, \\ Human-Tech Convergence Program, \\ Department of Clothing and Textiles, \\ Hanyang University, 222 Wangsimni-ro, \\ Seongdong-gu, Seoul 04763, Korea \\ Tel.: +82 222201191 \\ Fax: +82 222201856 \\ Email: khlee@hanyang.ac.kr
}

Received April 29, 2021

Revised May 23, 2021

Accepted June 03, 2021

Published June 30, 2021

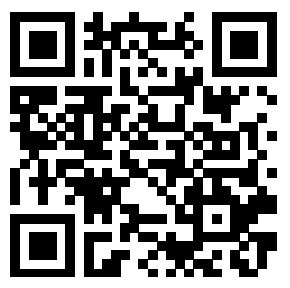

\begin{abstract}
Purpose: This study examines and compares Korean and Chinese consumers' perceptions of herbal cosmetics, as demand for natural cosmetics is increasing. Methods: Based on a big data methodology, this study uses text mining and semantic network analysis to identify major keywords that appeared in consumers' comments on herbal cosmetics. Results: Results reveal that Korean consumers paid more attention to herbal cosmetics products' distribution process and packaging conditions. Moreover, Korean consumers recognize herbal cosmetics as cosmetics for women of higher age. Chinese consumers focused more on the products' attributes, including other people's evaluations of the products and the ingredients of herbal cosmetics. Conclusion: As the market size of Korean herbal cosmetics expands, this study will help establish marketing strategies to target a wider consumer base and to provide basic data for establishing more effective marketing strategies when Korean herbal cosmetics brands enter the Chinese market.
\end{abstract}

Keywords: Herbal cosmetics, Consumer perception, Semantic network analysis, Clustering analysis, Unstructured data

\section{Introduction}

경제 발전으로 개인소득이 증가함에 따라 다양한 패션상품이나 인 테리어 제품뿐만 아니라 매일 사용하는 화장품에도 아낌없이 투자함 으로써 자신의 취향과 정체성을 표현하기 위해 노력한다. 이는 건강하 고 행복한 인생을 추구하는 웰빙(well-being) 가치가 삶에서 가장 중 요한 욕구로 여겨지면서 화장품에 대한 가치관이 변화했기 때문이다 (Lee \& Jung, 2012). 최근 건강의 범위가 개인을 넘어 환경적인 요소 까지 포함한 사회 차원으로 확대되었으며, 웰빙과 행복(happiness), 건 강(fitness)의 합성어이자 종합적으로 의미하는 웰니스(wellness)라는 개념이 등장하면서 자연주의, 지속가능성 등 친환경 산업에 대한 관심 과 수요가 높아지고 있다(Choe \& Rhie, 2019). 이런 웰니스 트렌드는 식품, 의류, 생활용품 등 다양한 분야에서 소비자 구매행동에 영향을 미치며, 비싼 가격이지만 몸에 좋은 천연제품을 선택하는 성향이 화장 품 시장에서도 지속적으로 증가하고 있다. 자연주의 화장품 중 비중이 가장 큰 것은 한방화장품으로 자연성분을 선호하는 소비자의 욕구를
만족시키면서 동양적 분위기를 추구하는 사회문화 트렌드와 맞물려 시장규모가 계속 커지고 있다(Wang et al., 2016).

2020년, 전 세계적으로 팬데믹(pandemic)이 장기화되면서 소비자 의 건강과 안전에 대한 욕구는 더욱 강해졌다. 온라인 유통시장에 익 숙한 젊은 소비자들도 안전과 건강에 민감해지고 자연에서 추출한 원 료를 이용한 한방화장품에 관심을 갖기 시작했다. 과거에는 고급스러 운 한국의 명품 화장품이라는 인식으로 중년층, 장년층의 전유물로 느 껴졌던 한방화장품의 소비 연령이 낮아지면서 젊은 소비자들을 공략 하려는 마케팅도 증가하고 있다.

웰빙 의식이 높아지면서 외모관리는 단순히 미용관리 개념에서 벗 어나 노화를 예방하고 최적의 건강상태를 유지하는 방법으로 이어지 고 있으며, 내면의 아름다움을 가꾸기 위해 노력하는 것까지 포함하게 되었다(Park \& Lee, 2019). 사람들은 외모관리를 통해 아름다운 외모 와 건강한 피부 상태를 유지하여 자아 이미지를 인식하고 심리적으로 자아실현을 이루고자 한다(Lee \& Jung, 2012). 이러한 외모관리행동 은 최종적으로 건강과 삶의 질을 향상시켜 행복을 느끼게 한다는 점에 
서 웰니스 트렌드와 관련 있으며, 자연주의 화장품에 대한 수요를 증 가시키는 원인 중에 하나로 파악되고 있다.

본 연구에서는 한방화장품의 주요 시장인 한국과 중국 소비자를 분 석 대상으로 설정하였다. 현재 $\mathrm{K}$ 뷰티는 한류 열풍을 타고 전 세계적 으로 관심이 높아지고 있다. 2019 화장품 산업 분석 보고서에 따르면 한국 화장품 수출액은 2018년 전년 대비 약 26.5\% 증가한 63억 달러 였으며(Jung \& Kim, 2020), 2019년에는 65억 달러에 달하여 세계 4 대 화장품 수출국가로 자리매김하였다(Oh, 2020). 특히 중국은 2018 년 기준 약 40 억 달러(63.4\%)의 수출규모로 가장 거대한 교역대상국으 로 보고되었다(KHISS, 2019). 중국이 한국 화장품 산업의 매우 중요 한 시장임을 알 수 있으므로, 한국 화장품 산업의 성장을 위해서는 중 국소비자에 대한 높은 이해가 요구된다.

한방화장품에 관한 선행연구는 주로 소비자 구매행동 분석(e.g., Eom \& Kim, 2004), 한방화장품의 브랜드 이미지(e.g., Kim, 2005), 유통경로에 따른 추구혜택 및 정보원에 관한 연구(e.g., Lee, 2007), 웰 빙 라이프스타일과 추구혜택과의 관계 연구(e.g., Choi, 2012), 패키지 에 나타난 디자인 표현 연구(e.g., Lee, 2018), 인식과 현황(e.g., Jung $\& \mathrm{Kim}, 2020 ; \mathrm{Kim}, 2007)$ 등의 영역에서 진행되었다. 국가간 비교 연구로는 소비자의 한방화장품에 대한 재구매의도(Sun \& Lee, 2015), 한중소비자 인식과 현황 비교(Wang et al., 2016), 한일 소비자 웰빙 외보관리 비교(Lee \& Jung, 2012) 등의 연구가 있었다. 주로 질적 연 구방법이나 설문지 결과를 비교 분석하는 양적 연구로 이루어졌다.

소비자들은 온라인에서 제품에 대한 정보를 알아보고 제품 및 서비 스를 다양한 방식으로 경험하여 정보를 공유하기도 한다. 온라인 거래 에 있어서 소비자 리뷰는 소비자의 심리를 이해할 수 있는 마케팅 자 원이자 제품의 개선 방향과 마케팅 전략의 방향성을 수립하는 데에 중 요한 역할을 한다(Chen \& Xie, 2008; Chen et al., 2011). 온라인 소 비자 리뷰는 온라인 구전(electronic word-of-mouth)의 형태로써 정 보 제공자와 추천자가 수행함으로써 잠재적 소비자의 구매결정이나 제품판매에 영향을 미치는 요인이다(Park et al., 2007). 특히 화장품 의 정보탐색은 주로 온라인에 남겨진 제품 리뷰, 사용경험을 전달하는 온라인 구전 형태로 이루어진다(Sohn et al., 2019). 제품에 대한 리뷰 는 소비자의 유입을 일으키기도 하고 반대로 소비자가 유출되는 단서 가 되기도 한다(Filieri \& McLeay, 2014). 이와 같은 온라인 리뷰를 비 롯한 각종 온라인 환경에서 생성되는 비정형 데이터와 수치화된 정형 데이터를 포함해 빅데이터(big data)라 한다(Eum et al., 2015). 빅데 이터를 활용하여 소비자들이 어떠한 의견과 인식을 나타내고 있는지 를 파악하는 네트워크 분석방법은 기존의 설문지 조사보다 확대된 범 위의 정보를 얻을 수 있을 뿐만 아니라 다수의 소비자를 대상으로 한 연구를 진행하기 어려운 시점에도 적용할 수 있는 장점이 있다(Lee \& Jung, 2020). 따라서 소비자 온라인 리뷰의 중요성을 고려하여 본 연 구에서는 텍스트 마이닝(text-mining)과 내용분석(content analysis) 을 통해 소비자들의 반응을 파악하고자 한다.

본 연구는 아시아 화장품 시장의 주류 국가인 한국과 중국 소비자
를 대상으로 선정하였으며, 최근 소비자들의 한방화장품에 대한 인식 을 살펴보고자 하였다. 의미 네트워크 분석을 사용함으로써 소비자 리 뷰에 출현한 한방화장품 관련 주요 키워드를 알아보고, 리뷰들을 긍 정, 부정 두 가지 감정으로 분류하여 감성에 따른 인식을 분석하고자 한다. 또한 한국과 중국의 비정형 데이터를 수집하고 분석함으로써 사 회적, 문화적 특성에 어떤 차이가 있는지를 알아보았다. 한방화장품의 시장 규모가 확대됨에 따라 더욱 넓어진 소비자층을 공략하기 위한 마 케팅 전략을 수립하는 데에 도움이 되고자 하며, 향후 보다 효과적인 마케팅 전략을 수립하는 데에 기초자료가 될 것을 기대한다.

\section{Methods}

\section{1. 소비자 데이터 수집}

한국과 중국 소비자들의 한방화장품에 대한 인식을 분석하기 위 해 의미 네트워크 분석을 실시하였다. 소비자 리뷰 데이터를 수집할 한방화장품 브랜드와 제품은 다음의 과정을 거쳐 선정하였다. 한국 포털사이트 네이버(Naver)를 통해 2019년 12월 1일부터 2020년 12 월 1 일까지, 한방화장품 브랜드 검색 빈도수를 조회한 결과, '설화수 (88,200건)', '더 후(12,030건)'의 순으로 빈도수가 나타났다. 중국 포 털 사이트 바이두(Baidu)에서 2019년 12월 1일부터 2020년 12월 1 일까지 최근 일년 간의 일평균 검색빈도를 조회한 결과, 마찬가지로 ' 설화수(1,334건)'가 가장 높은 빈도수를 보인 한방화장품 브랜드로 나 타났으며, 그 다음은 '더 후(1,275건)' 순으로 나타났다. 최상위 빈도 수를 보인 '설화수'와 '더 후'를 연구대상 브랜드로 선정하였다.

한방화장품에 대한 소비자 인식을 알아보기 위해 제품을 구매한 소 비자의 텍스트 리뷰를 수집했다. 본 연구에서는 한방화장품을 스킨케 어 부문과 메이크업 부문으로 나누어 부문 내 가장 많은 리뷰를 보유 한 제품을 분석대상으로 선정하였는데, 2021년 1월 기준, 한국 네이 버 쇼핑(http://shopping.naver.com)에서 설화수를 검색한 결과, 총 47,734 개의 제품이 검색되었다. 스킨케어 제품으로는 자음 기획세트 (39,278건), 메이크업 제품으로는 파운데이션 쿠션(3,255건)이 가장 많은 리뷰 수를 차지하는 것으로 나타났다. 이어서 중국 온라인 오픈 마켓인 타오바오(http://taobao.com)에서 '설화수'를 검색한 결과, 한 국과 동일하게 스킨케어 부문은 자음 기획세트(96,636건), 메이크업 부문은 파운데이션 쿠션(17,745)이 가장 많은 리뷰 수를 차지하고 있 는 것으로 확인되었다. 한편, 네이버 쇼핑에서 '더 후'를 검색한 결과, 스킨케어 부문은 공진향 기획세트( 3,184 건), 메이크업은 비비 크림 ( 1,181 건)으로 가장 많은 리뷰 수를 차지하는 것으로 나타났으며, 타 오바오의 경우 스킨케어는 천기단 기획세트(142,554), 메이크업은 립 스틱 $(1,766)$ 이 누적 리뷰 수가 가장 많은 제품으로 집계되었다. 이에 본 연구에서는 스킨케어 제품과 메이크업 제품 각 2 개씩, 총 4 개의 한 방화장품 제품을 분석에 포함되었다. 또한 데이터 수집에는 중국의 비정형 데이터 수집 플랫폼인 바즈와유(bazhuayu)를 이용하였으며, 
2017년 1월 1일부터 2021년 1월 1일까지 작성된 리뷰로 한정하여 각 제품별 1,000 개의 리뷰를 수집하였다.

본 연구에서는 소비자 감성에 따른 네트워크의 구조를 파악하기 위 해 제품의 평점을 추출하였다. 소비자들이 제품 리뷰 시 부여하는 평 가점수는 제품에 대한 소비자의 내적 감정을 수치화한 것이라 할 수 있다. 이에 수집된 리뷰들을 1-2점은 부정, 3점은 중립, 4-5점은 긍 정으로 분류하였으며, 중립을 제외한 긍정과 부정 네트워크의 특성을 비교 및 분석하였다. 분류된 리뷰 중 스킨케어 부문의 한국 소비자 긍 정 데이터는 1,349 건, 부정은 268 건이었으며, 메이크업 부문에서 긍 정 데이터는 1,728 건, 부정은 231 건이었다. 한편, 스킨케어 부문에서 수집된 중국 소비자의 긍정 데이터는 1,675 건, 부정은 258 건이며, 메 이크업 부분에서는 긍정과 부정 데이터가 각각 1,533 건, 154 건이 수 집되었다.

\section{2. 분석방법 및 연구문제}

의미 네트워크 분석은 네트워크 형태에서 관계성을 도출하여 체계 의 특성을 설명할 수 있는 방법으로, 이를 구성하는 단위 간의 관계 를 분석함으로써 사람들의 사회적 행위와 그들이 맺은 관계로 형성 된 네트워크의 특성을 설명할 수 있다(Choi \& Lee, 2019). 연결정도 중심성은(degree centrality)는 한 노드(node)가 다른 노드와 직접적 으로 연결되어 있는 정도를 설명하는 통계적 지표이다(Ahn \& Park, 2019). 연결정도가 클수록 더 넓은 폭과 자율성을 갖게 되어 네트워 크 내에서 영향력이 커진다는 것을 의미한다. 따라서 공정한 지수 비 교를 위해 상대적인 값으로 연결정도 중심성 지수를 정규화 하여 분 석에 적용하였다(Seon et al., 2020). 특정 노드에 직접적으로 연결 된 다른 노드의 개수를 반영하는 연결정도 중심성과 달리, 아이겐벡 터 중심성(eigenvector centrality)은 한 노드와 연결된 다른 노드의 중요도를 반영하여 그 노드의 영향력이 어느 정도로 나타나는지를 설 명한다(Ahn \& Park, 2019). 수집된 리뷰 중 광고성 단어와 관사, 전 치사, 조사, 접속사 등의 불용어를 1 차 정제한 뒤 형태소 분석을 진 행하였다. 데이터 정제, 형태소 분석 및 $\mathrm{TF}-\mathrm{IDF}$ 값 추출에는 텍스톰 (textom)을 이용하였으며, 네트워크의 해석에 사용된 연결정도 중심 성, 아이겐벡터 중심성 지수와 네트워크 클러스터링 시각화 자료는 NodeXL 프로그램(The Social Media Research Foundation, USA)을 통해 확보하였다.

한방화장품의 한국 소비자와 중국 소비자의 인식 차이를 파악하고 각 클러스터에 나타난 제품별 특성의 차이점을 살펴보기 위하여 다음 과 같이 연구문제를 설정하였다.

연구문제 1. 한방화장품에 대한 한국과 중국 소비자들의 전반적인 인식을 제품군 별로 알아보고 비교한다.

연구문제 2. 한방화장품에 대한 한국과 중국 소비자들의 감성을 제 품군 별로 군집화(clustering)하여 비교한다.

\section{Results and Discussion}

\section{1. 한방화장품에 대한 한중 소비자 인식 비교}

1) 스킨케어 제품군 의미 네크워크 분석 비교

네트워크 분석을 위해 수집된 리뷰 데이터 중 불필요한 키워드를 정제하고 $\mathrm{TF}-\mathrm{IDF}$ 값 기준 상위 80 개 단어를 추출하였으며, 결과는 Table 1 에 상위 20 위까지 정리하였다. 먼저, 한방화장품 스킨케어 부 문에 대한 한국 소비자의 키워드를 살펴본 결과, 최상위 10 개의 키워 드는 '선물', '포장', '배송', '샘플', '어머니', '가격', '만족', '상자', '사은 품', '쇼핑백'이었다. 노드(node)의 연결정도를 나타나내는 연결정도 중심성 지수 $\left(\mathrm{C}_{\mathrm{A}}\right)$ 를 기준으로 보았을 때, '배송(0.97)', '선물(0.94)', '샘 플(0.91)', '포장(0.90)', '백화점(0.85)', '가격(0.85)', '상자(0.84)', '머니 $(0.82)$ ', '사은품(0.81)', '만족(0.76)' 등이 주요 키워드로 나타났다. 한 방화장품을 구매하였을 때 구매결정에 상대적으로 더 많은 영향을 미 치는 요소는 선물포장의 상태, 샘플 또는 사은품의 증정여부와 가격 에 대한 요인임을 알 수 있었다. 그리고 선물-포장, 포장-상자, 선 물-배송, 선물-어머니 등의 키워드 간 연결강도가 가장 강한 것을 확 인하여 한방화장품은 다소 높은 연령대의 여성들에게 사용되는 화장 품으로 인지되고 있음을 확인할 수 있었다. 또한 '브랜드( 0.39$)$ ', '고급 $(0.35)^{\prime}$ 키워드도 연결되어 나왔는데, 이는 한방화장품 브랜드가 가진 고급스러운 이미지로 인해 한방화장품 구매동기가 주로 여성 시니어 소비자를 위한 명절, 기념일 등의 선물용에 있음을 설명할 수 있다.

한편, 중국 소비자들의 리뷰를 분석한 결과, $\mathrm{TF}-\mathrm{IDF}$ 값을 기준으 로 '효과', '피부', '상담원', '향기', '사은품', '정품', '평가', '샘플', '촉촉하 다', '이벤트' 등의 순으로 나타났다. 연결정도 중심성 값을 기준으로 살펴보았을 때, '평가(0.87)', '효과(0.86)', '향기(0.85)', '샘플(0.84)', '정 품(0.82)', '상담원(0.82)', '피부(0.82)', '촉촉하다(0.73)', '사은품(0.73)', '질감 $(0.66)$ ' 등이 주요 키워드로 나타났다. '효과'와 연결되는 키워드는 '피부', '질감', '평가', '향기', '촉촉하다'로 나타났고 '피부'와 '향기', '질감' 은 서로 연결되었다. 한국 소비자에 비해 중국 소비자가 제품 평가에 더 많은 영향을 받는 것으로 설명할 수 있으며, 중국 소비자가 한방화 장품의 향기, 질감 등을 비롯한 제품 속성을 가장 중요시하기 때문으 로 보인다. '서비스', '태도', '참을성'은 '상담원' 키워드와 연결성을 보여 상담원에 대한 언급이 많았음을 알 수 있다. 이는 중국 온라인 유통 시 장이 발달함에 따라 온라인 상담원의 역할이 중요해지고 있어 상담원 에 대한 인상이 브랜드 이미지의 일부로 인식되고 있음을 설명한다.

전체적으로 보았을 때, 한국에서는 '배송 $\left(\mathrm{C}_{\mathrm{e}}=0.024\right)$ ', '선물 $\left.\left(\mathrm{C}_{\mathrm{e}}=0.023\right)\right)^{\prime}$, '포장 $\left(\mathrm{C}_{\mathrm{e}}=0.023\right)^{\prime}$ 키워드의 아이겐벡터 중심성 $\left(\mathrm{C}_{\mathrm{e}}\right)$ 이 가장 높게 나타나 강한 영향력을 보이는 반면, 중국에서는 '평가 $\left(\mathrm{C}_{\mathrm{e}}=0.025\right)$ ', '효과 $\left(\mathrm{C}_{\mathrm{e}}=0.024\right)$ ' 그리고 '향기 $\left(\mathrm{C}_{\mathrm{e}}=0.024\right)$ '의 아이겐벡터 중심성이 가장 높은 키워드로 나타났다. 이는 한국 소비자가 화장품 유통과정과 포장상태에 대해 더욱 중요시하는 측면이 있음을 의미하 며, 중국 소비자는 한국 소비자와 달리 제품에 대한 타인의 평가와 한 방화장품의 제품 속성을 더 많이 중시하였음을 알 수 있다. 즉, 한국 
소비자에게 한방화장품은 연령대가 높은 여성의 화장품으로 인식되었 던 반면 중국 소비자는 타인의 한방화장품에 대한 평가와 제품 자체의 속성이 중요한 개념으로 인지되고 있었다고 해석할 수 있다.

한방화장품 스킨케어 부분에 있어 한국 소비자와 중국 소비자의 리 뷰 중 공통적으로 나타난 키워드 수가 전체 키워드의 $21 \%$ 가량 나타 나 한국과 중국의 소비자가 몇 가지 측면에서 같은 인식을 공유하고 있는 것으로 설명할 수 있다(Figure 1). '어머니'와 '선물'은 여성 시니 어 대상의 선물용으로 인식하는 것을 의미하며 한국과 중국 소비자가 모두 인지하고 있었다. Wang et al. (2016)을 비롯한 한방화장품의 사 용실태에 관한 선행연구의 결과에서도 한방화장품은 연령대가 높은 사람들이 사용하는 제품이라는 인식을 보였음이 밝혀져 본 연구의 결 과를 지지한다. 또한 '상담원', '지인' 키워드가 한국과 중국 소비자 리 뷰에서 모두 출현한 것은 소비자의 구매결정 과정에서 중요한 역할을 한 것으로 설명할 수 있다. 이는 Sun \& Lee (2015)의 연구에서 한국 과 중국 소비자의 한방화장품 구매동기로 판매원이나 지인 권유에 대 한 요인이 규명되어 본 연구 결과를 지지한다. 피부와 관련된 키워드
로 '복합성', '건성', '건조', '유분', '트러블' 등이 한국과 중국 소비자 리 뷰에서 공통적으로 나타났는데, 이는 다양한 피부타입에 따라 피부보 호를 위해 한방화장품을 선택하는 것으로 인지된다고 설명할 수 있다. '가격' 외에도 '가성비', '할인', '저렴', '면세점'과 같은 경제성 키워드가 공통적으로 출현한 것은 한국과 중국 소비자 모두 한방화장품 구매에 있어 가격이 주요 고려 요인 중 하나로 인식된 것으로 설명할 수 있다. 한국과 중국 소비자의 한방화장품에 대한 인식 차이를 분석한 결 과, 한국 소비자 리뷰 중에 '비싸다', '최저가', '상품권'과 같은 키워드는 한방화장품의 가격에 대한 관심도가 높게 나타난 것으로 설명된다. ' 구성', '쇼핑백' 등 패키지와 관련된 키워드는 한국 소비자가 제품 포장 에 대해 중요시하는 것으로 해석된다. 한국 소비자 리뷰 중 '홈쇼핑', ' 백화점'과 같은 유통채널에 관련된 키워드가 나타난 반면 중국 소비자 리뷰에는 '라이브커머스'가 나타났다. 이는 최근 중국에서 라이브커머 스를 통해 각종 할인과 증정 이벤트를 진행하고 있음을 알 수 있다. 또 한 한국 소비자는 제품의 유통기한, 패키지 포장 등에 관심이 많았으 나 중국 소비자 리뷰에서는 '코로나', 건강과 연관된 '인삼', '생강', '성

Table 1. TD-IDF and centralities of the top 20 herbal cosmetic skincare keywords

\begin{tabular}{|c|c|c|c|c|c|c|c|c|}
\hline \multirow{2}{*}{ No. } & \multicolumn{4}{|c|}{ Korea } & \multicolumn{4}{|c|}{ China } \\
\hline & Keyword & TF-IDF & $\mathrm{C}_{\mathrm{d}}^{\mathrm{a}}$ & $\mathrm{C}_{\mathrm{e}}^{\mathrm{b}}$ & Keyword & TF-IDF & $\mathrm{C}_{\mathrm{d}}$ & $\mathrm{C}_{\mathrm{e}}$ \\
\hline 1 & Shipping & 776.08 & 0.97 & 0.024 & Evaluation & 403.79 & 0.87 & 0.025 \\
\hline 2 & Present & 914.75 & 0.94 & 0.023 & Effect & 700.38 & 0.86 & 0.025 \\
\hline 3 & Sample & 616.00 & 0.91 & 0.023 & Smell & 489.08 & 0.85 & 0.024 \\
\hline 4 & Package & 873.10 & 0.90 & 0.023 & Sample & 394.53 & 0.84 & 0.024 \\
\hline 5 & Department store & 336.15 & 0.85 & 0.022 & Genuine product & 405.91 & 0.82 & 0.024 \\
\hline 6 & Price & 518.99 & 0.85 & 0.022 & $\begin{array}{l}\text { Customer service } \\
\text { agent }\end{array}$ & 534.79 & 0.82 & 0.024 \\
\hline 7 & Box & 497.27 & 0.84 & 0.022 & Skin & 549.02 & 0.82 & 0.024 \\
\hline 8 & Mother & 585.32 & 0.82 & 0.021 & Moist & 390.04 & 0.73 & 0.023 \\
\hline 9 & Gift & 444.19 & 0.81 & 0.021 & Gift & 475.25 & 0.73 & 0.022 \\
\hline 10 & Satisfaction & 517.74 & 0.76 & 0.019 & Texture & 307.52 & 0.66 & 0.021 \\
\hline 11 & Composition & 371.45 & 0.76 & 0.020 & Brand & 237.29 & 0.62 & 0.020 \\
\hline 12 & Shopping bag & 419.03 & 0.68 & 0.019 & Greasy & 246.94 & 0.61 & 0.020 \\
\hline 13 & Disappoint & 243.14 & 0.66 & 0.018 & Event & 344.64 & 0.58 & 0.020 \\
\hline 14 & Image & 201.28 & 0.63 & 0.017 & Price & 258.78 & 0.56 & 0.019 \\
\hline 15 & Skin & 280.88 & 0.61 & 0.016 & Comfortable & 158.62 & 0.53 & 0.018 \\
\hline 16 & Express & 172.03 & 0.61 & 0.017 & Friend & 227.65 & 0.53 & 0.018 \\
\hline 17 & Repurchase & 327.13 & 0.58 & 0.016 & Service & 272.03 & 0.52 & 0.017 \\
\hline 18 & Return & 127.56 & 0.58 & 0.017 & Attitude & 200.46 & 0.49 & 0.017 \\
\hline 19 & State & 159.42 & 0.53 & 0.015 & Discount & 188.72 & 0.48 & 0.017 \\
\hline 20 & Omission & 161.52 & 0.52 & 0.015 & Fake & 207.61 & 0.47 & 0.015 \\
\hline
\end{tabular}

a, degree centrality; b, eigenvector centrality.

Note: TF-IDF is an indicator of the importance of a particular keyword according to its frequency; $C_{d}$ represents the degree of connectivity of nodes, and $\mathrm{C}_{\mathrm{e}}$ is a centrality indicator that reflects the importance of other nodes connected to one node. 
분' 등 한방화장품의 원재료에 관한 키워드가 나타나 제품 성분에 대 한 관심이 많다는 것을 보여준다. Wang et al. (2016)과 Jung \& Kim (2020)의 연구결과에 따르면, 한국과 중국 소비자 모두가 한방화장품 의 성분에 대해 신뢰하며, 피부에 안전한 화장품으로 인식한 것으로 나타났다. 또한 일반화장품과 구분할 때, 한국 여성은 한방화장품을 한약재로 제조된 화장품이라고 인식하였지만 중국 여성 소비자는 동 양의학의 영향으로 한방화장품이 피부에 자극이 적어 가장 안전할 것 으로 인식하였다는 차이를 보여주고 있어 본 연구의 결과와 유사하다 (Jung \& Kim, 2020; Wang et al., 2016). 이는 근래의 웰니스 트렌드 에 맞물리고 특히 팬데믹 사태 이후 중국 소비자의 안전과 건강에 대 한 욕구가 더욱 강해지면서 자연주의 화장품인 한방화장품에 대한 수 요가 증가한 것과 연관된다 할 수 있다.

\section{2) 메이크업 제품군 의미 네크워크 분석}

한방화장품 메이크업 부분에 대한 리뷰들을 살펴보고 TF-IDF 값 을 기준으로 상위 80 개 키워드를 선정하였고, Table 2 에 상위 20 위까
지 나타냈다. 한방화장품 메이크업 부분에 대한 한국 소비자의 리뷰 를 분석한 결과, '배송', '어머니', '만족', '선물', '커버력', '샘플', '호수', ' 재구매', '피부' 등의 순으로 나타났다. 연결정도 중심성 값을 기준으로 는 '커버력(0.81)', '피부(0.80)', '만족(0.77)', '선물(0.75)', '샘플(0.71)', ' 배송(0.70)', '어머니(0.66)', '호수(0.62)', '색상(0.53)', '건조(0.53)' 등이 주요 키워드로 나타났다. 한방화장품 메이크업 부분에서는 다른 일반 화장품과 유사하게 화장품 자체의 속성과 사용감이 소비자가 가장 중 요시하는 요인으로 나타났다. 스킨케어 부분에서 출현한 '선물', '어머 니', '포장' 키워드는 메이크업 부분에서도 높은 연결중심성을 보이며, 한국 소비자가 한방화장품의 제품 종류와 관계없이 여성 시니어가 주 로 사용하는 화장품이라 인식한 것으로 설명할 수 있다. 또한 '어머니' 와 연결된 '선물', '포장', '배송', '만족' 키워드는 가장 높은 연결강도를 나타내며, 메이크업 부분에서도 여성 시니어의 선물용 제품으로 인식 되었음을 알 수 있다.

한편, 한방화장품 메이크업 부분에 대한 중국 소비자의 리뷰 분석 결과, TF- $\mathrm{IDF}$ 값 기준 '색상', '사은품', '효과', '촉촉하다', '샘플', '상담

Table 2. TD-IDF and centralities of the top 20 herbal cosmetic makeup keywords

\begin{tabular}{|c|c|c|c|c|c|c|c|c|}
\hline \multirow{2}{*}{ No. } & \multicolumn{4}{|c|}{ Korea } & \multicolumn{4}{|c|}{ China } \\
\hline & Keyword & TF-IDF & $\mathrm{C}_{\mathrm{d}}{ }^{\mathrm{a}}$ & $\mathrm{C}_{\mathrm{e}}{ }^{\mathrm{b}}$ & Keyword & TF-IDF & $\mathrm{C}_{\mathrm{d}}$ & $\mathrm{C}_{\mathrm{e}}$ \\
\hline 1 & Coverage & 461.58 & 0.81 & 0.027 & Color & 557.21 & 0.86 & 0.027 \\
\hline 2 & Skin & 333.89 & 0.80 & 0.027 & Moist & 441.38 & 0.76 & 0.025 \\
\hline 3 & Satisfaction & 485.20 & 0.77 & 0.027 & Effect & 456.50 & 0.76 & 0.025 \\
\hline 4 & Present & 484.26 & 0.75 & 0.026 & Gift & 517.74 & 0.76 & 0.025 \\
\hline 5 & Sample & 402.57 & 0.71 & 0.024 & Skin & 259.99 & 0.73 & 0.025 \\
\hline 6 & Shipping & 593.98 & 0.70 & 0.024 & Sample & 412.44 & 0.70 & 0.024 \\
\hline 7 & Mother & 534.73 & 0.66 & 0.024 & Evaluation & 245.35 & 0.68 & 0.022 \\
\hline 8 & Shade & 382.04 & 0.62 & 0.020 & $\begin{array}{l}\text { Customer service } \\
\text { agent }\end{array}$ & 318.69 & 0.66 & 0.021 \\
\hline 9 & Color & 289.90 & 0.53 & 0.020 & Coverage & 296.74 & 0.65 & 0.022 \\
\hline 10 & Dry & 147.75 & 0.53 & 0.020 & Long-wear & 244.51 & 0.59 & 0.021 \\
\hline 11 & Defect & 113.13 & 0.52 & 0.020 & Greasy & 126.96 & 0.59 & 0.022 \\
\hline 12 & Recommendation & 203.73 & 0.52 & 0.020 & Event & 232.78 & 0.56 & 0.021 \\
\hline 13 & Case & 172.45 & 0.52 & 0.020 & Genuine product & 199.78 & 0.54 & 0.020 \\
\hline 14 & Repurchase & 380.55 & 0.51 & 0.019 & Cost-effective & 120.86 & 0.53 & 0.021 \\
\hline 15 & Price & 294.51 & 0.49 & 0.018 & Friends & 127.57 & 0.53 & 0.019 \\
\hline 16 & Long-wear & 183.91 & 0.48 & 0.018 & Adherence & 122.69 & 0.52 & 0.020 \\
\hline 17 & Gift & 244.48 & 0.48 & 0.019 & Makeup & 158.62 & 0.51 & 0.019 \\
\hline 18 & Package & 217.01 & 0.48 & 0.019 & Brand & 115.06 & 0.49 & 0.019 \\
\hline 19 & Dull & 196.67 & 0.47 & 0.019 & Skin tone & 200.39 & 0.48 & 0.019 \\
\hline 20 & Makeup & 112.11 & 0.44 & 0.018 & Live commerce & 143.39 & 0.47 & 0.018 \\
\hline
\end{tabular}

$a$, degree centrality; $b$, eigenvector centrality.

Note: TF-IDF is an indicator of the importance of a particular keyword according to its frequency; $\mathrm{C}_{\mathrm{d}}$ represents the degree of connectivity of nodes, and $\mathrm{C}_{\mathrm{e}}$ is a centrality indicator that reflects the importance of other nodes connected to one node. 


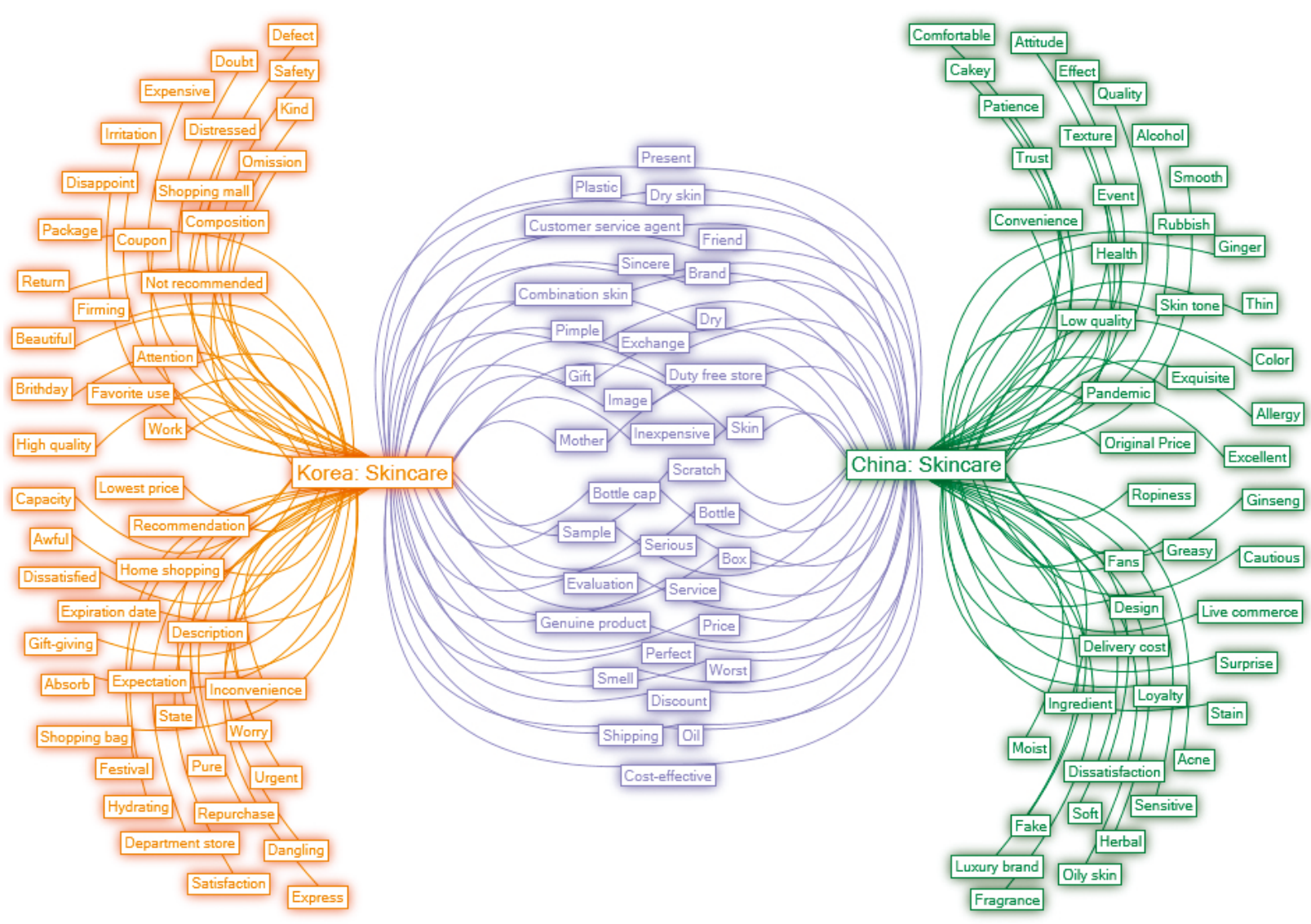

Created with NodeXL Pro (http://nodexl.codeplex.com) from the Social Media Research Foundation (http://www.smrfoundation.org)

Figure 1. Common and independent keywords about herbal cosmetic skincare: Korea vs China.

This network was visualized based on Korean and Chinese consumers' reviews regarding herbal cosmetic skincare products. The keywords gathered at the center are common cognitive factors; in each aspect, the keywords represent discriminatory cognitive factors.

원', '커버력', '피부', '평가', '지속력' 등의 순으로 나타났다. 연결정도 중심성 값을 기준으로 보았을 때, '색상(0.86)', '촉촉하다(0.76)', '효과 (0.76)', '사은품(0.76)', '피부(0.73)', '샘플(0.70)', '평가(0.68)', '상담원 (0.66)', '커버력(0.65)', '지속력(0.59)' 등이 주요 키워드로 나타났다. 그리고 '색상', '커버력', '지속력' 등 화장품 속성에 관련된 단어가 '효과' 와 가장 높은 연결강도를 보였다. 메이크업 제품에 있어 한국 소비자 는 여성 시니어가 사용하는 화장품으로 인식한 것과 달리 중국 소비 자는 화장품 속성, 정품 여부 그리고 실제 사용효과에 대해 더 많은 관 심을 보였다. 전체적으로 살펴보면, 한국에서는 '커버력 $\left(\mathrm{C}_{\mathrm{e}}=0.027\right)$ ', ' 만족 $\left(\mathrm{C}_{\mathrm{e}}=0.027\right)$, '피부 $\left(\mathrm{C}_{\mathrm{e}}=0.027\right)$ '가 가장 높은 아이겐벡터 중심성 과 연결강도를 보이는 반면 중국에서는 '색상 $\left(\mathrm{C}_{\mathrm{e}}=0.027\right)$ ', '촉촉하다 $\left(\mathrm{C}_{\mathrm{e}}=0.025\right)$ ' 그리고 '사은품 $\left(\mathrm{C}_{\mathrm{e}}=0.025\right)$ ' 키워드가 가장 높은 값을 보였 다. 또한 '상담원', '서비스', '이벤트', '샘플' 등의 키워드가 '라이브커머 스'와 연결되어 스킨케어 뿐만 아니라 메이크업 부분에서도 출현하였 다. 이는 최근 중국 온라인 쇼핑 플랫폼에서 라이브커머스의 비중이
급속도로 확대되고 있기 때문이다. 라이브커머스는 온라인 유통채널 로서 소비자의 한방화장품 구매과정에서 중요한 역할을 한 것으로 설 명할 수 있다.

한방화장품 메이크업 부분에 있어 한국 소비자와 중국 소비자의 리 뷰에서 공통적으로 출현한 키워드 수가 전체 키워드의 $25 \%$ 를 차지한 것은 제품속성, 가격 그리고 실제 사용효과에 대해 같은 인식으로 인 지하고 있는 것으로 설명할 수 있다(Figure 2). 비교 분석한 결과, 한 국 소비자의 네트워크에서 '누렇다', '비싸다', '약하다', '어둡다', '어렵 다' 등 제품 속성에 관한 형용사 위주로 출현한 것은 한방화장품의 메 이크업 제품이 일반화장품과 큰 차이가 없는 것으로 인식하고 있음을 의미한다. 반면, 중국 소비자의 리뷰 중 '신뢰', '충성', '팬', '한결같다', ' 의외성(惊喜)', '명품' 등의 키워드가 나타난 것은 중국 소비자가 한방 화장품에 높은 만족도와 신뢰도를 가지고 있어 한방화장품 브랜드에 대한 충성도가 높다는 것으로 설명할 수 있다. 이는 한국 여성 소비자 보다 중국 여성 소비자가 한방화장품에 대한 신뢰정도가 더 높은 것으 


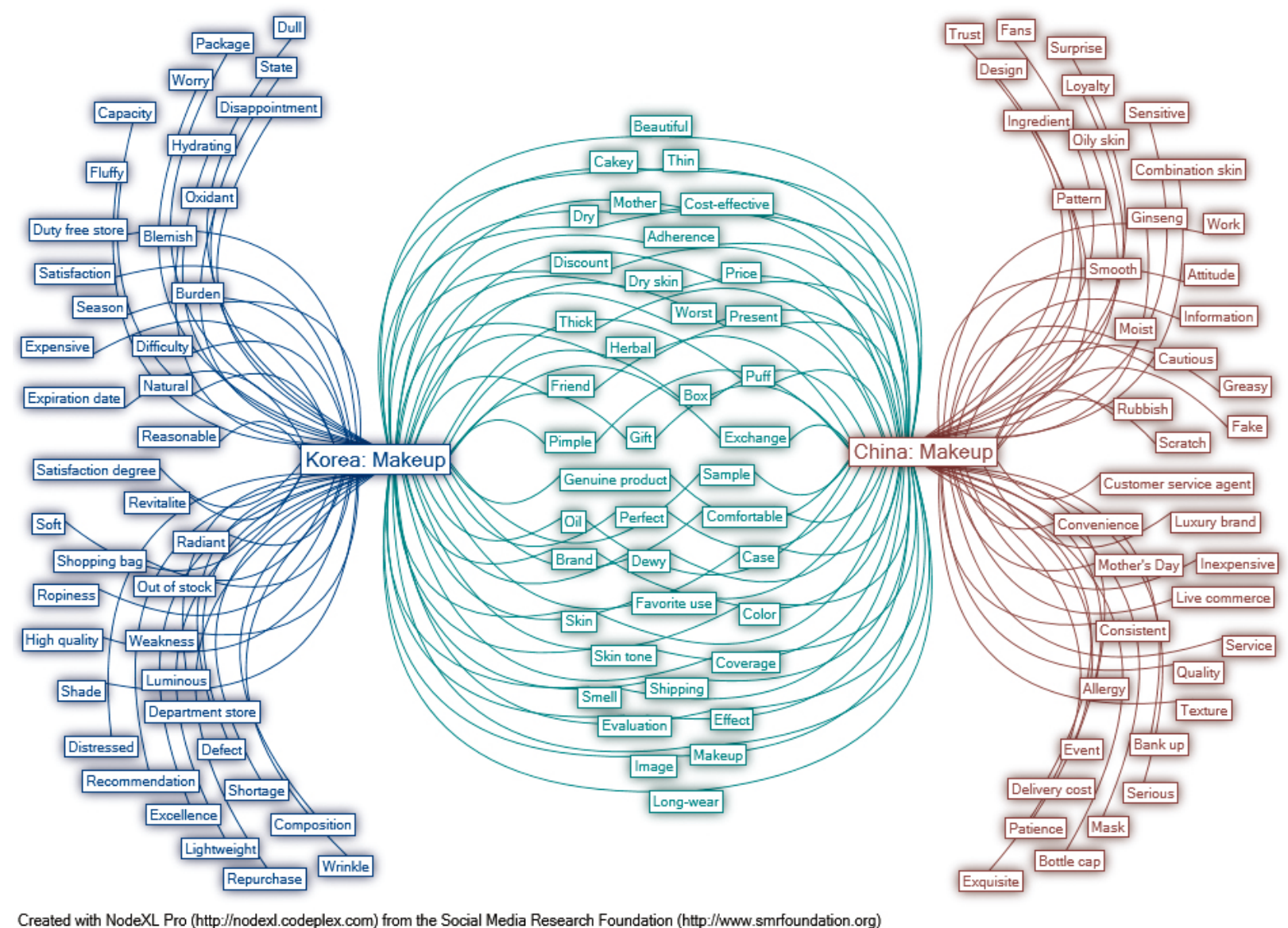

Figure 2. Common and independent keywords about herbal cosmetic makeup: Korea vs China.

This network was visualized based on Korean and Chinese consumers' reviews regarding herbal cosmetic makeup products. The keywords gathered at the center are common cognitive factors; in each aspect, the keywords represent discriminatory cognitive factors.

로 나타났던 Sun \& Lee (2015)의 결과와 유사하여 본 연구 결과를 지 지한다. 또한 Wang et al. (2016)의 연구에서 일반화장품보다 한방화 장품이 더 좋은지에 대해서 한국 소비자보다 중국 소비자가 더 많은 분포로 나타났으며, 중국 소비자가 한방화장품에 대한 선호도가 높은 편인 것으로 나타나 본 연구결과와 일치한다.

\section{2. 한방화장품에 대한 한중 소비자 리뷰 클러스터 비교}

긍정 리뷰와 부정 리뷰만을 사용하여 소비자의 한방화장품에 대한 감성 클러스터를 알아보았다. TF- $\mathrm{DF}$ 값 기준으로 각 상위 60 개 키워 드를 선정하고. 키워드의 상관관계를 바탕으로 노드 5 개 이상으로 형 성된 그룹만을 대상으로 군집분석을 실시하였다. Clauset-NewmanMoore 알고리즘을 사용하여 시각화 하였고 구조적으로 유사한 계층 을 가진 노드들이 하나의 군집에 표현되었다(Clauset et al., 2008).

\section{1) 스킨케어 제품: 클러스터링}

한방화장품 스킨케어 부분에 대한 한국 소비자의 긍정 리뷰를 총
$1,349$ 개 수집하였고, 4 가지 클러스터로 분류되었다(Figure $3 \mathrm{~A})$. 분석 결과, '선물', '샘플', '상품권' 등이 하나의 클러스터로 형성되었으며 선 물에 대한 내용으로 볼 수 있다. '포장', '상자', '사은품'은 강한 연결성 을 보였고 '최고', '택배', '추천' 키워드와 연결된 것은 한국 소비자가 한 방화장품 패키지에 대한 만족도가 높은 것으로 설명할 수 있다. 또한, '배송', '어머니', '가격', '만족' 등의 키워드는 소비자가 구매결정을 내릴 때 고려한 요인으로 볼 수 있다. '피부', '품질', '향기', '부드럽다' 등의 단어는 제품 속성이 반영된 키워드로 한국 소비자의 한방화장품에 대 한 인식으로 볼 수 있다. 한편, 부정 리뷰는 총 268 개 수집되었으며 3 가지 클러스터로 분류되었다(Figure 3B). '선물', '누락', '구성', '상자', ' 용기', '쇼핑백' 등 제품 구성과 관련된 키워드가 한 클러스터로 형성된 것은 실제 제품을 수령할 때 제품 상세정보와 다른 제품을 받았거나 제품 누락의 문제가 발생하였음을 알 수 있다. '포장', '배송', '샘플', '택 배' 등의 키워드는 유통과정과 관련된 문제로 볼 수 있다. 고객 관리를 의미하는 '상담원', '반품', '교환' 등의 키워드는 소비자가 구매과정에서 느끼는 서비스에 대한 부정적인 감정을 반영하는 것으로 볼 수 있을 
A

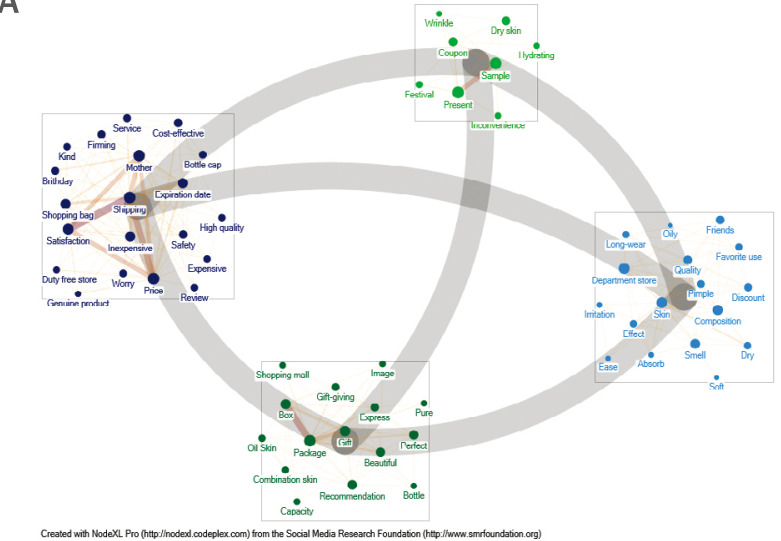

C

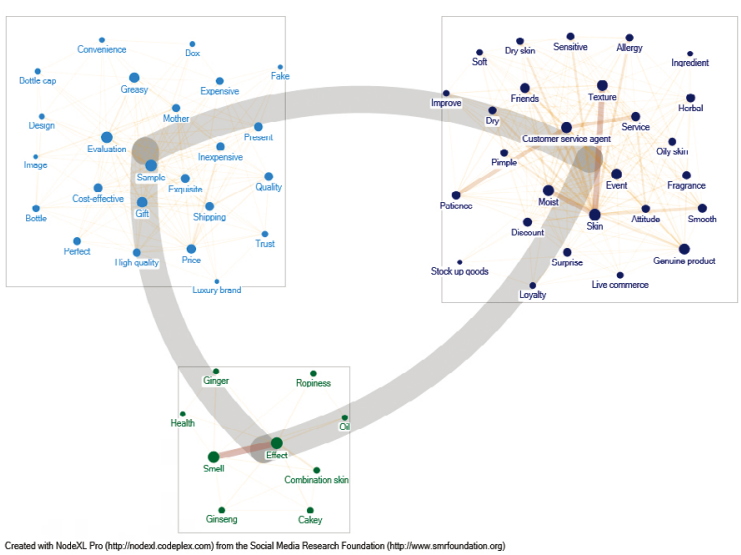

B

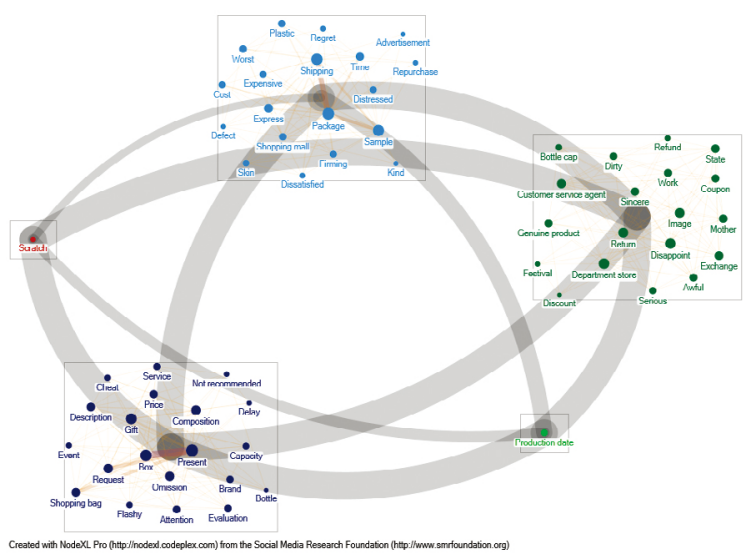

D

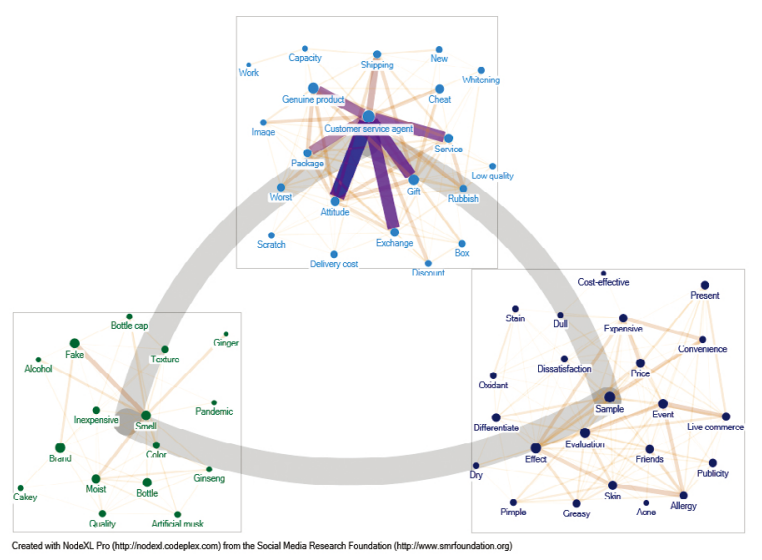

Figure 3. Network clusterings of herbal cosmetic skincare keywords using CNM algorithm.

(A) Positive reviews from Korean consumers. (B) Negative reviews from Korean consumers. (C) Positive reviews from Chinese consumers. (D) Negative reviews from Chinese consumers.

것이다. $\operatorname{Eom} \& \operatorname{Kim}$ (2004)의 연구에서 한방화장품 구입시 판매원의 설명을 통해 판단한다는 소비자가 가장 많았던 것을 감안하면 고객과 의 관계를 관리할 수 있는 방안이 마련되어야 할 것으로 보인다.

중국의 경우, 긍정 리뷰는 1,675 개를 수집되었고 이를 분석한 결 과, 총 3개의 클러스터로 분류되었다(Figure $3 \mathrm{C}$ ). '가성비', '비싸다', ' 저렴'과 같은 가격에 대한 단어와 '정교하다', '고급', '품질' 등의 키워드 가 연결이 된 것은 중국 소비자의 한방화장품에 대한 평가로 볼 수 있 다. '정품', '이벤트', '할인' 등 경제성 키워드가 '피부', '질감', '촉촉하다', '의외성' 등 긍정적 제품 속성과 서로 연결성을 보여 중국 소비자의 한 방화장품에 대한 선호도가 높은 것을 볼 수 있다. '향기', '인삼', '생강', '건강' 등 원재료와 관련된 키워드가 긍정적 제품 속성과 서로 연결 이 된 것은 중국 소비자가 한방화장품 성분에 대한 관심도가 높고 사 용 효과에 대해 긍정적인 반응을 보인 것으로 설명할 수 있다. 이와 같 은 결과는 중국 소비자들이 한방화장품에 대하여 피부에 안전할 것 같 다는 긍정적인 인식을 보인 선행연구 결과와 유사하다(Wang et al., 2016). 부정적인 리뷰는 258 개를 수집하여 3 가지 클러스터로 분류되
었다(Figure 3D). '상담원', '태도', '교환', '사은품', '정품', '포장' 등 고 객 관계 관리에 관련된 키워드가 서로 강한 연결강도를 보인 것을 알 수 있었다. 이는 중국 소비자가 온라인 구매과정에서 상담원 태도, 사 은품 누락, 제품 포장 상태와 교환의 어려움 등 여러 문제를 겪음에 따 라 고객 관계 관리와 서비스에 대한 불만을 호소한 것으로 해석된다. ' 피부', '알레르기', '노랗다', '어둡다', '트러블' 등 사용 효과에 대한 키워 드가 서로 연결되어 실제 사용 효과에 대한 소비자의 부정적인 감정이 리뷰를 통해 나타나고 있었다. Wang et al. (2016) 연구에서 채택을 주저하는 동기로 한방화장품이 자신의 피부에 적합하지 않을 것이라 는 응답을 보인 것과 같은 맥락에 있다고 할 수 있다. '냄새', '위조품', ' 용기' 등의 키워드가 한 클러스터로 형성된 것은 중국 소비자의 한방 화장품 제품 속성에 대한 의견으로 볼 수 있다. '냄새', '인조향', '알코 올'과 '생강', '인삼' 등 한방 원재료 관련 단어가 연결되어 한방화장품 특유의 냄새에 대한 불만이 리뷰에서 거론되는 것을 알 수 있다. 긍정 리뷰에서도 향기에 대한 내용이 나온 반면 부정 리뷰에서도 나타난 것 은 소비자 개인의 취향에 따라 향에 대해 지각되는 인식이 각기 다르 
A

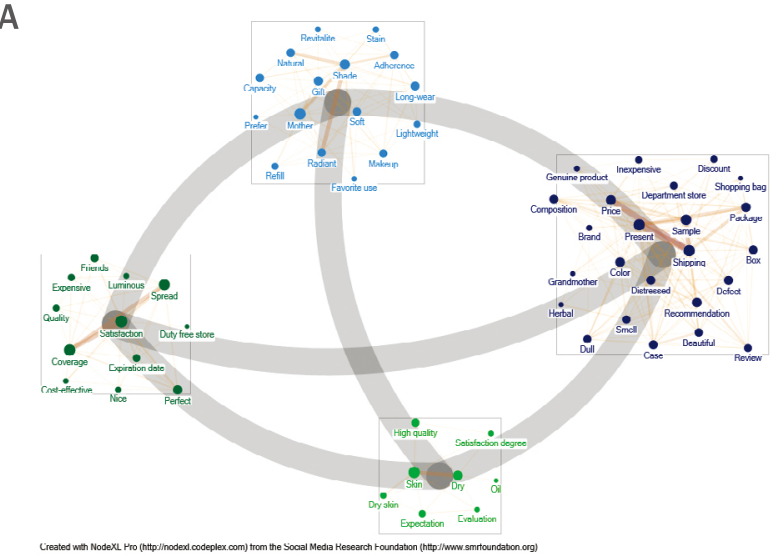

C

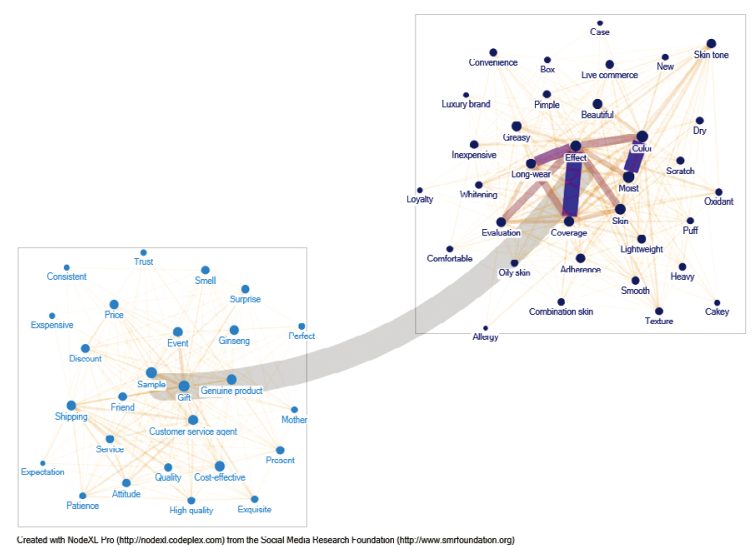

B

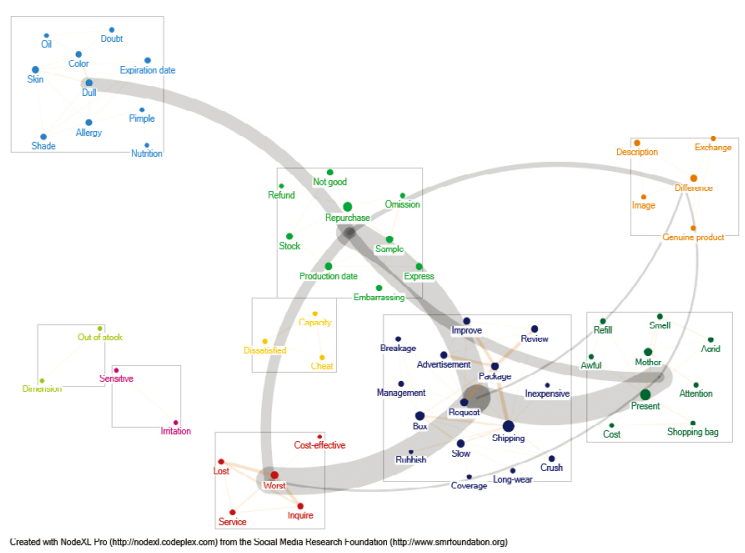

D

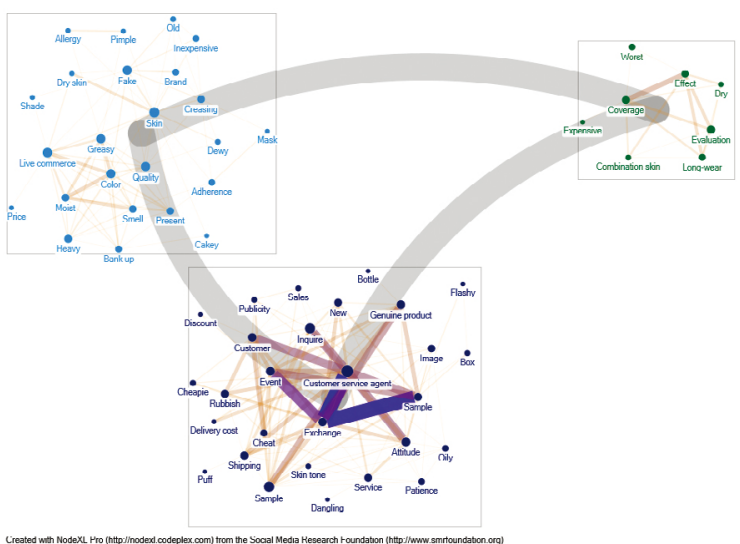

Figure 4. Network clusterings of herbal cosmetic makeup keywords using CNM algorithm.

(A) Positive reviews from Korean consumers. (B) Negative reviews from Korean consumers. (C) Positive reviews from Chinese consumers. (D) Negative reviews from Chinese consumers.

기 때문으로 볼 수 있다. 또한 '위조품', '뚜껑', '색상' 등에 대한 단어는 부정적인 리뷰에서만 나타나 중국 소비자가 위조품에 대한 의심, 용기 에 대한 불편함 등에 대해 갖는 아쉬운 감정을 확인할 수 있었다. 기존 한방화장품의 포장디자인이 해외 소비자 니즈에 부합하지 않는다고 하였던 Hong (2017)의 연구와 유사한 결과를 보여 이에 대한 해결 조 치를 마련할 필요가 있다고 보인다.

\section{2) 메이크업 제품: 클러스터링}

한방화장품 메이크업 부분에 대한 한국 소비자의 긍정 리뷰 1,728 개를 수집하여 4 가지 클러스터로 분류하였다(Figure $4 \mathrm{~A})$. 분석 결과, '선물', '배송', '가격', '포장', '추천' 등 선물에 관련된 키워드가 한 클러 스터로 형성된 것은 한국 소비자가 한방화장품을 선물용으로 인지하 는 것으로 볼 수 있다. '건조' 등 피부에 관련된 내용은 다수의 소비자 가 한방화장품을 건성 피부에 부합한 제품으로 인식하고 있음을 의미 한다 할 수 있다. '호수', '자연스럽다', '밝다', '지속력' 등 사용 효과에 대한 단어는 '어머니'와 연결되어 한방화장품이 여성 시니어에게 선호
도가 높은 화장품인 것으로 설명할 수 있다. '유통기한', '비싸다', '가 성비', '최고' 등 경제성 단어가 긍정 리뷰에서 나타나 한방화장품 가격 대에 대한 한국 소비자의 긍정적인 관심을 알 수 있다. Eom \& Kim (2004)의 연구에서 한방화장품에 대한 비싸다는 인식과 가격에 대한 불만족이 평균 이상으로 나타난 것과는 차이가 있는 결과라 할 수 있 는데, 가격에 민감한 소비자를 고려한 브랜드 마케팅 효과의 일환으 로도 볼 수 있을 것이다. 반면, 부정 리뷰 231개에 대한 클러스터의 경우(Figure 4B), '배송', '포장', '요청', '광고' 등의 키워드 간 연결성 이 강하여 한국 소비자가 제품 포장을 중요시하는 것을 알 수 있다. 선물', '냄새', '독하다' 등 선물에 대한 내용이 부정 리뷰에서 나타난 것 은 소비자가 선물용으로 구매한 경험 중에 느꼈던 아쉬운 점에 대해 토로한 것이라 할 수 있다. '민망', '샘플', '누락', '환불' 등은 소비자의 서비스에 대한 불만으로 볼 수 있다. '알레르기', '어둡다', '색상' 등 피 부와 관련된 키워드는 제품 속성에 대한 부정적인 감정이라고 설명할 수 있다.

중국의 경우, 긍정 리뷰 1,533 개를 수집하여 클러스터링한 결과, 2 
개의 클러스터로 분류되었다(Figure 4C). '효과', '커버력', '색상', '촉촉 하다', '지속력', '피부' 등 제품속성 관련 키워드 간 강한 연결성을 보여 한방화장품의 실제 사용 효과에 대한 중국 소비자의 만족도가 높은 것으로 설명할 수 있다. '사은품', '샘플', '상담원', '이벤트', '할인' 등 유 통과 서비스에 관련된 키워드가 한 그룹으로 형성되었다. 이는 중국 소비자가 제품속성에 긍정적인 감정을 가지고 있을 뿐 아니라 유통 과정과 서비스도 중요시하는 것으로 설명할 수 있다. 반면, 부정 리뷰 는 총 154 개이며, 3 개의 클러스터로 분류되었다(Figure 4D). '효과', ' 커버력', '지속력'등의 키워드와 서로 연결 관계를 보여 일부 소비자 가 제품 속성에 불만족한 것으로 보인다. 또한 '위조품', '품질', '색상', '냄새', '기름지다' 등 키워드 간의 연결성을 통해 위조품에 대한 우려 와 품질에 대한 내용을 언급하는 것을 확인할 수 있었다. 한편, 위조 품에 대한 우려는 스킨케어 클러스터링 결과에서도 언급되었는데, 선 행연구를 참고하여 정품임을 나타낼 수 있는 포장디자인과 브랜드 이 미지 정보를 전달할 있는 커뮤니케이션 방법이 필요할 것으로 보인다 (Hong, 2017). '상담원'과 '태도', '샘플', '교환,' '이벤트', '소비자', '이벤 트' 등의 키워드가 서로 높은 연결성을 보여 한방화장품 브랜드의 고 객 관계 관리에 대한 중국 소비자의 불만이 리뷰에 반영되었다고 할 수 있다. 이는 중국 온라인 시장의 규모가 확대됨에 따라 온라인 상담 원의 역할이 중요해지면서 중국 소비자에게 있어 온라인 상담원의 서 비스와 태도가 구매결정에 중요한 요인으로 작용하는 것으로 설명할 수 있다.

\section{Conclusion}

본 연구는 한국과 중국 소비자를 대상으로 네트워크 분석과 클러 스터링 분석을 실시하였다. 한방화장품에 대한 리뷰를 수집하여 주요 키워드를 도출한 후 비교함으로써 한국과 중국 소비자의 한방화장품 에 대한 인식 차이를 알아보았다.

전체적으로 한국소비자의 인식을 나타내는 주요 키워드는 '배송', 선물', '샘플', '포장', '어머니'로 나타났다. 한국 소비자의 한방화장품 구매결정에 상대적으로 더 많은 영향을 미치는 요소는 선물포장 상 태, 샘플이나 사은품의 증정 여부, 가격 요인임을 알 수 있었다. 한 편, 중국 리뷰에서는 '평가', '효과', '향기', '상담원'이 주요 키워드로 나 타나 중국 소비자가 한방화장품의 향기, 질감 등을 비롯한 제품 속성 을 가장 중시하는 것으로 설명할 수 있다. 또한 한국 소비자는 화장품 유통 과정과 포장 상태에 대해 더 중시하였으며, 한방화장품은 연령 대가 높은 여성의 화장품으로 인식되는 것을 확인할 수 있었다. 중국 소비자는 한국 소비자와 달리 한방화장품의 원재료 등을 비롯한 제 품 속성을 더 많이 중시하였으며, 한방화장품에 대한 타인의 평가를 중요한 요소로 인지하고 있음을 알 수 있었다. 이는 여러 선행연구에 서 실증된 결과(e.g., Wang et al., 2016; Sun \& Lee, 2015; Jung \& $\mathrm{Kim}, 2020)$ 와 유사하게 나타나 본 연구결과를 지지한다.
한국과 중국 소비자 리뷰를 긍정적 감정과 부정적 감정으로 나누 어 클러스터링 분석한 결과, 한국 소비자가 한방화장품 패키지와 제 품 속성에 대해 긍정적 반응을 보였으며, 여성 시니어에게 사용하기 좋은 화장품으로서 선물용으로 높은 만족감을 보인 것으로 나타났다. 반면, 부정적인 리뷰에서는 제품속성에 대한 불만족, 제품구성에 대 한 아쉬움, 배송지연을 비롯한 유통문제, 고객 관리에 대한 불쾌감이 나타났다. 한편, 중국 소비자의 경우 한방화장품의 제품 속성, 사용효 과, 유통과 서비스에 대한 긍정적인 감정이 리뷰에 반영되었으며, 부 정적인 리뷰에서는 주로 냄새나 질감 등의 제품 속성과 상담원을 비 롯한 고객관리에 대한 불만이 나타났다. 분석 결과를 바탕으로 부정 적 리뷰에서 언급된 문제는 최우선적으로 해결되어야 하며, 배송, 서 비스 등 부정적 리뷰에 대한 해결방안을 마련할 필요가 있을 것이다.

본 연구의 결과와 선행연구(e.g., Wang et al., 2016; Jung \& $\mathrm{Kim}, 2020)$ 에서도 나타나듯, 한국과 중국 소비자에게 한방화장품 은 높은 연령대의 여성들이 사용하는 화장품이라는 이미지가 인식되 어 있다. 젊은 소비자를 타겟으로 확대하기 위해서는 사용경험이 없 는 소비자에게 다양한 샘플 및 사은품으로 구성되는 세트 제품을 출 시하고 젊은 층의 피부 타입에 맞추어 제품 효능, 효과를 개선할 필요 가 있다. 또한 각종 유통채널을 통해 한방화장품 브랜드 아이덴티티 에 적합한 홍보 방안을 고려해야 한다. 특히 중국의 경우 라이브커머 스 산업이 확대되고 있어 이를 통해 이벤트를 진행함과 동시에 고급 스러운 이미지로 스토리텔링하여 충성 고객층을 확보해야 한다. 고객 관리 측면에서는 온라인 상담원의 역할이 중요해진 만큼 고객 관리 방안을 보완할 필요가 있다고 본다.

본 연구에서는 빅데이터를 활용한 의미 네트워크 분석과 클러스터 링 분석 방법론을 적용하여 한국과 중국 소비자의 한방화장품에 대한 인식을 알아보았다. 한방화장품의 시장 규모가 확대됨에 따라 더 넓 어진 소비자층을 공략하기 위한 마케팅 전략을 수립하는 데에 기초자 료가 되기를 기대한다.

\section{Author's contribution}

XKF, JHS, and KHL contributed equally to this study. XKF and JHS designed this study together, and XKF wrote the manuscript. XKF collected and analyzed the survey data, and JHS assisted and engaged in data visualization and analysis. KHL oversaw all aspects of this study and reviewed the results of the analysis.

\section{Author details}

Xuan-Kun Fan (Graduate student), Human-Tech Convergence Program, Department of Clothing and Textiles, Hanyang University, 222 Wangsimni-ro, Seongdonggu, Seoul 04763, Korea; Joon-Ho Seon (Graduate student), Human-Tech Convergence Program, Department 
of Clothing and Textiles, Hanyang University, 222 Wangsimni-ro, Seongdong-gu, Seoul 04763, Korea; KyuHye Lee (Professor), Human-Tech Convergence Program, Department of Clothing and Textiles, Hanyang University, 222 Wangsimni-ro, Seongdong-gu, Seoul 04763, Korea.

\section{References}

Ahn S, Park B. Characteristics of Youtube video network of creative consumption and analyses of consumer responses through comments: focusing on lkea hack. Journal of Consumption Culture, 22: 95-118, 2019.

Chen Y, Fay S, Wang Q. The role of marketing in social media: how online consumer reviews evolve. Journal of Interactive Marketing, 25: 85-94, 2011.

Chen Y, Xie J. Online consumer review: word-of-mouth as a new element of marketing communication mix. Management Science, 54: 477-491, 2008.

Choe JA, Rhie JM. Analysis of transitions on healing-related concepts and trends: focusing on well-being, wellness, and healing keywords. Journal of Basic Design \& Art, 20: 597-612, 2019.

Choi SK. A study on relationship between well-being lifestyles and herbal cosmetics benefits sought of female consumers. Journal of the Korean Fashion \& Costume Design Association, 14: 49-62, 2012.

Choi YH, Lee KH. Diffusion of veganism in fashion and beauty: a semantic network analysis. Journal of the Korean Society of Costume, 69: 75-94, 2019.

Clauset A, Moore C, Newman MEJN. Hierarchical structure and the prediction of missing links in networks. Nature, 453: 98-101, 2008.

Eom JN, Kim JD. An empirical study on the oriental herbal cosmetics purchase behaviors in women in the metropolitan area. Journal of the Society of Cosmetic Scientists of Korea, 30: 93-102, 2004.

Eum HK, Chang HJ, Choi DJ, Park SC. A study on big data utilization scheme for the city branding: focused on the 'user-centered typology in Seoul city'. A Journal of Brand Design Association of Korea, 13: 193-206, 2015.

Filieri R, McLeay F. E-wom and accommodation: an analysis of the factors that influence travelers' adoption of information from online reviews. Journal of Travel
Research, 53: 44-57, 2014.

Hong X. Studies on package design of oriental medicine cosmetics for exporting to foreign countries: focusing on Gyeongbuk oriental medicine cosmetics. Journal of Korea Design Forum, 54: 67-78, 2017.

Jung HI, Kim JD. A study on the consumer awareness and usage status of herbal cosmetics. Journal of the Korean Society of Cosmetics and Cosmetology, 10: 93-105, 2020.

KHISS (KHIDI, KHIDI Brief Vol. 278: 2020 Korea health industry export outlook), 2019. 3. 8.

Kim HR. A study on the brand image of Korean herbal cosmetics. Korean Journal of Korean Medical Institute of Dermatology \& Aesthetics, 1: 98-113, 2005.

Kim JD. The prospects and current situation of oriental herbal cosmetics. Journal of the Korean Society of Fashion \& Beauty, 5: 1-7, 2007.

Lee JY, Jung HJ. Exploring consumers' perceptions of bags using the SNS big data. A Journal of Brand Design Association of Korea, 18: 55-70, 2020.

Lee SM. A study on the benefits sought information sources utilized by consumers based on the distribution channels of herbal cosmetics. Family and Environment Research, 45: 33-44, 2007.

Lee $\mathrm{Y}$, Jung $\mathrm{HJ}$. The effects of well-being consciousness and appearance management of Korean and Japanese consumers on attitudes toward Korean herbal cosmetics. Journal of the Korean Society of Costume, 62: 87-102, 2012.

Lee YH. A study of design expressions in the packages of Korean herbal medicine cosmetics. $A$ Treatise on The Plastic Media, 21: 28-37, 2018.

Oh YK. Effects of cosmetics purchase decision factors of female university students in Korea and Taiwan on the Korea cosmetics satisfaction. Asian Journal of Beauty and Cosmetology, 18: 619-628, 2020.

Park DH, Lee J, Han I. The effect of on-line consumer reviews on consumer purchasing intention: the moderating role of involvement. International Journal of Electronic Commerce, 11: 125-148, 2007.

Park JY, Lee MS. Influence of beauty care on well-beingoriented behaviors and well-aging behaviors in adult men. Asian Journal of Beauty and Cosmetology, 17: 93-106, 2019. 
Seon JH, Park SM, Lee KH. Fashion product development with unstructured data mining: applying consumer responses to up-cycling. Journal of the Korean Society of Costume, 70: 61-75, 2020.

Sohn HJ, You SH, Park CH. Relationship between consumers' exploring cosmetics information behavior and satisfaction and recommendation intention. Asian Journal of Beauty and Cosmetology, 17: 499-509, 2019.
Sun YP, Lee SS. A study on female Korean and Chinese consumers' re-purchase intention of Korean herbal cosmetics. The Konkuk Journal of Business and Economic Studies, 40: 253-286, 2015.

Wang JD, Seo HS, Lee EH. A comparative study for Korea and Chinese women about herbal cosmetics. Journal of the Korean Society of Cosmetics and Cosmetology, 6: 43-55, 2016. 


\section{국문초록}

\section{한방화장품에 대한 한중 소비자 인식: 클러스터링 분석}

범선쿤, 선준호, 이규혜

한양대학교 의류학과 휴먼테크융합전공, 서울, 한국

목적: 본 연구는 자연주의 화장품에 대한 수요가 증가하는 시점에 한국과 중국 소비자를 대상으로 한방화장품에 대한 인식을 살펴 보고 비교하고자 하였다. 방법: 빅데이터 방법론을 바탕으로 텍스트 마이닝과 의미 네트워크 분석을 사용하여 한방화장품 관련 리 뷰에 나타난 주요 키워드를 알아보았다. 클러스터링 분석을 통해 감정별로 소비자의 한방화장품에 대한 인식을 분석하고 군집화 하 여 비교하였다. 결과: 한국 소비자는 화장품 유통과정과 포장상태에 대해 더 중요시하였으며, 한방화장품을 연령대가 높은 여성의 화장품으로 인식하였음을 확인할 수 있었다. 중국 소비자는 한방화장품의 원재료 등을 비롯한 제품 속성을 더 많이 중시하였으며, 한방화장품에 대한 타인의 평가를 중요한 요소로 인지하고 있음을 알 수 있었다. 결론: 한방화장품의 시장 규모가 확대됨에 따라 더 욱 다양해지고 젊어진 소비자층을 공략하기 위한 마케팅 전략을 수립하는 데에 도움이 되고자 하며, 보다 효과적인 마케팅 전략 수 립에 활용할 수 있는 기초자료를 제공하고자 한다.

핵심어: 한방 화장품, 소비자 인식, 의미 네트워크 분석, 클러스터링 분석, 비정형 데이터

\section{참고문헌}

김주덕. 한방 화장품의 현황 및 전망. 한국패션뷰티학회지, 5: 1-7, 2007.

김혜랑. 한방화장품의 브랜드 이미지에 관한 연구. 대한한방피부미용학회지, 1: 98-113, 2005.

박재영, 이명선. 성인 남성의 미용관리가 웰빙지향 행동과 웰에이징 행위에 미치는 영향. 아시안뷰티화장품학술지, 17 :

93-106, 2019.

보건산업통계(한국보건산업진흥원, 보건산업브리프 Vol. 278: 2020 국내 보건산업 수출 전망), 2019. 3.8.

선유평, 이승신. 한·중 여성소비자의 한국 한방화장품 재구매의도. 商經研究, 40: 253-286, 2015.

선준호, 박선미, 이규혜. 비정형 데이터 마이닝을 이용한 패션제품 개발: 업사이클링에 대한 소비자 의견을 중심으로. 복 식, 70: $61-75,2020$.

손효정, 유선희, 박초희. 소비자의 화장품 정보탐색행동과 만족도 및 추천의도의 관계 연구. 아시안뷰티화장품학술지, 17 : 499-509, 2019.

안서원, 박병화. 창의적 소비에 대한 유튜브 비디오 네트워크의 특성과 댓글을 통한 소비자 반응 분석: Ikea hack을 중심 으로. 소비문화연구, 22: 95-118, 2019.

엄정녀, 김주덕. 한방 화장품 구매행동에 관한 실증적 연구: 수도권 거주 여성 소비자를 중심으로. 대한화장품학회지, 30 : 93-102, 2004.

엄희경, 장혜정, 최두진, 박성찬. 도시브랜딩을 위한 빅데이터 활용에 관한 연구: 서울시 수요자 유형분석을 중심으로. 브 랜드디자인학연구, 13: 193-206, 2015.

오윤경. 한국과 대만 여대생의 화장품 구매결정요인이 한국화장품의 만족도에 미치는 영향. 아시안뷰티화장품학술지, 18: 619-628, 2020.

왕준적, 서현숙, 이은희. 한·중 여성들의 한방화장품에 관한 비교연구. 한국화장품미용학회지, $6: 43-55,2016$. 이승민. 유통경로에 따른 한방 화장품 추구혜택 및 정보원에 관한 연구. 대한가정학회지, 45: 33-44, 2007. 이영화. 한방화장품 패키지에 나타난 디자인 표현 연구. 조형미디어학, 21: 28-37, 2018.

이유리, 정혜정. 한국과 일본 소비자의 웰빙의식과 외모관리에 따른 한방화장품 태도 연구. 복식, 62: 87-102, 2012. 
이지연, 정혜정. SNS 빅데이터를 활용한 가방(Bag)에 대한 소비자 인식 분석. 브랜드디자인학연구, 18: 55-70, 2020. 정혜일, 김주덕. 한방화장품에 대한 인식과 사용 실태에 관한 연구. 한국화장품미용학회지, 10: 93-105, 2020.

최수경. 여성소비자의 웰빙 라이프스타일과 한방화장품 추구혜택과의 관계 연구. 한국의상디자인학회지, 14: 49-62, 2012.

최영현, 이규혜. 패션·뷰티 소비에서 비거니즘의 확산: 의미네트워크분석. 복식, 69: 75-94, 2019.

최지안, 이진민. 힐링(Healing)과 연관된 개념의 변천과 트렌드 동향 분석: 웰빙(Well-being), 웰니스(Wellness), 힐링 (Healing)의 키워드를 중심으로. 기초조형학연구, 20: 597-612, 2019.

홍흠. 중국 수출시장 진출을 위한 한방화장품 포장디자인 연구: 경북 한방화장품을 중심으로. 한국디자인포럼, $54: 67-$ 78, 2017. 


\section{中文摘要}

\section{韩国和中国消费者对草药化妆品的看法：非结构化数据分析}

范璇坤, 宣俊豪, 李揆惠 ${ }^{*}$

汉阳大学服装学科人类科技融合专业, 首尔, 韩国

目的: 随着对天然化妆品的需求不断增加, 本研究调查并比较韩国和中国消费者对草药化妆品的看法。方法: 本 研究基于大数据方法, 利用文本挖掘和语义网络分析来识别消费者对草本化妆品的评论中出现的主要关键词。 结果: 结果显示, 韩国消费者更关注草药化妆品的分销过程和包装条件。此外, 韩国消费者认为草本化妆品是适 合高龄女性的化妆品。中国消费者更关注产品的属性, 包括其他人对产品的评价和草药化妆品的成分。结论: 随 着韩国草药化妆品市场规模的扩大, 本研究将有助于制定营销策略以针对更广泛的消费者群体, 并为韩国草药 化妆品品牌进入中国市场时制定更有效的营销策略提供基础数据。

关键词: 草药化妆品, 消费者认知, 语义网络分析, 聚类分析, 非结构化数据 
